\title{
INTEGRATIVE SOIL AND LEAFY APPLICATION OF NPK FERTILIZERS IMPROVES GROWTH, YIELD, ANTIOXIDANT AND NUTRIENT STATUS OF CAPSICUM ANNUUM L. 1. UNDER SANDY SOIL CONDITIONS
}

Khaulood A. Hemida ${ }^{a}$, Abdullah Z.A. Eloufey ${ }^{b}$, Gamal M. Hassanc, and Mostafa M. Rady

${ }^{a}$ Botany Department, Faculty of Science, Fayoum University, Fayoum, Egypt

${ }^{\mathbf{b}}$ Botany Department, Faculty of Agriculture, Fayoum University, Fayoum, Egypt

${ }^{\mathbf{c}}$ Genetics Department, Faculty of Agriculture, Fayoum University, Fayoum, Egypt

ABSTRACT

The appropriate application method was specified using integrative soil and leafy application of NPK fertilizers to sandy soil by studying their effects on growth and yield components, contents of some osmoprotectants, antioxidants and nutrients in hot pepper plant "Top Star Hybrid". A pot experiment was created with five NPK application treatments. The integrative treatment of " $50 \%$ of NPK added to the soil $+50 \%$ of NPK added as foliar spray" was the best comparing with other integrative ones [e.g., " $100 \%$ of NPK added to the soil + foliar spray with distilled water (control)", " $75 \%$ of NPK added to the soil $+25 \%$ of NPK added as foliar spray", " $25 \%$ of NPK added to the soil $+75 \%$ of NPK added as foliar spray", and "NPK fertilizers have not been added to the soil $+100 \%$ of NPK added as foliar spray"]. This best treatment significantly increased the components of growth (leaf area plant ${ }^{-1}$, shoot fresh and dry weights) and yield (number of fruits plant ${ }^{-1}$, average fruit weight, and fruits weight plant ${ }^{-1}$ ), and the contents of soluble sugars, free proline, and nutrients (N, P, and $\mathrm{K}$ ), while significantly reduced the contents of ascorbate and glutathione compared to other integrative treatments, including the control. The integrative treatment of " $75 \%$ of NPK added to the soil $+25 \%$ of NPK added as foliar spray" was occupied the second order with respect to all tested parameters. The obtained results recommend the integrative treatment of " $50 \%$ of NPK added to the soil $+50 \%$ of NPK added as foliar spray" for sandy soil to minimize nutrient loss and for higher growth and yield of hot pepper plants.

Keywords: Pepper, nutrients application, sandy soil, growth and productivity, antioxidants

\section{INTRODUCTION}

Belonging to Solanaceae, pepper is the second most important vegetable crop after tomato. It encompasses about 30 species, but Capsicum annuum L. is the most cultivated species in both tropical and temperate zones (Grubben and El Tahir, 2004). Pepper has economic, nutritional and medicinal values. It is an excellent source of natural colors and antioxidant compounds (Dagnoko et al., 2013; FAOSTAT, 2012).

Soil texture varies with particles size from clay (fine) through silt (medium) to sand (coarse). The larger the particles the larger the spaces among them, so that water drains quickly through sand. Texture affects the soil's ability to retain water and nutrients. Sand doesn't retain nutrients very tightly, so as water drains through sandy soil carrying nutrients along with it out of the root zone and makes them

Fayoum J. Agric. Res. \& Dev., Vol. 34, No.2 July, 2020 
Khaulood A. Hemida et al.

unavailable to plants (Yolcubal et al., 2004; Magdoff and van Es, 2009). The term "nutrient loss" is expressed as the amount of nutrients lost from soil in water or sediment (Schick et al., 2000). Soil type and its cation exchange capacity (CEC), fertilizer amount, and time and application method of fertilizer are the most factors, which affect nutrient loss (Mello, 2002; Bertol et al., 2003). CEC is a measure of soil capacity, nutrient availability, soil $\mathrm{pH}$ and soil responses to fertilizers and other ameliorants (Hazleton and Muephy, 2007). CEC of the soil directly affects the amount of fertilizer and the frequency of fertilizer use. Soil with very low CEC, such as sand, requires small amounts of fertilizer on a frequent basis because it suffers from the loss of cations easily, and becomes iondeficient. Soil with lower CEC is likely to develop deficiencies in $\mathrm{K}^{+}, \mathrm{Mg}^{2+}$, and others (CUCE, 2007).

Nutrients application to soil is necessary and the most common practice in soil fertilization but as described before it has many limitations with respect to nutrient bioavailability for plants. Therefore, it is important to find other strategies for applying and managing fertilizers due to their pivotal roles in plant growth and development, up-regulation of plant physio-biochemistry, and controlling plant diseases (Dordas, 2008). It's well known that leaves can absorb nutrients as natural process by which plants obtain additional nutrients from spraying solutions. This principle is used in agriculture by spraying plant leaves with dilute solutions of the required nutrients. Foliar application could be considered one of the most common methods, which are used to deliver the nutrients needed for plants with adequate concentrations, improve plant nutritional status, and increase crop yield and quality (Smoleń, 2012).

Foliar fertilization has the potential to improve the efficiency and speed of using urgently required nutrients by the plant to maximize growth and yield (Oosterhuis, 1995). Foliar application of nutrients can also provide faster response and allow deficiencies to be corrected in less time than can be achieved through soil application. The main advantage of foliar fertilization is the immediate uptake of applied micro (e.g., Fe, Mn, $\mathrm{Zn}, \mathrm{Cu}$, etc.) and macronutrients (e.g., N, P, K, etc.) in smaller amounts without causing any phytotoxicity (Oosterhuis and Weir, 2010) when practiced properly. Foliar fertilization could also be used under farming conditions as (1) a quick remediation for unexpected deficiencies, (2) as a preventive measure against unsuspected (hidden) deficiencies, (3) for late supply of $\mathrm{N}$ during advanced growth stages, and (4) to overcome fixation of nutrients in defected soils (Stepien and Katarzyna, 2016).

Soil application of fertilizers is mainly performed on the basis of soil tests, whereas foliar nutrient applications are mainly conducted on the basis of visual foliar symptoms or plant tissue tests. Hence, correcting diagnosis of nutrient deficiency is fundamental for successful foliar fertilization (Fageria et al., 2009). Additionally, foliar application of nutrients could be considered cost-effective if implemented to obtain crops biofortified with micronutrients and trace elements deficient in the diet of human who live in certain environments (Smoleń, 2012). If a nutrient deficiency occurs in plants, its foliar supplement will be faster to restore the nutrient than adding it to the soil. This due to that foliar uptake of mineral

Fayoum J. Agric. Res. \& Dev., Vol. 34, No.2 July, 2020 
INTEGRATIVE SOIL AND LEAFY APPLICATION OF NPK..................15 nutrients is ranged from 8 to 20 times more efficient than soil application (Alshaal and El-Ramady, 2017). The timing of foliar spraying, especially in relation to the stage of growth, could be considered critical for the optimal efficacy of foliar treatment, and more attention should be paid to it (Alexander, 1986). The effectiveness of foliar nutrition is affected by numerous endogenous (related to leaf anatomical structure) and exogenous (nutrient concentration, soil type, $\mathrm{pH}$, etc.) environmental factors.

Growth, yield, and quality of a plant species differ with soil types, soil nutrient status, and fertilizer management. The plant species requires suitable soil for higher yield and better quality (Akamine et al., 2007; Chowdhury et al., 2008; Islam et al., 2011), besides, the proper application method of fertilizers should be considered. Soil fertility and crop productivity differ significantly with the amount and combination of nutrients (e.g., K, Ca, Mg, S, P, Fe, N, etc.) and $\mathrm{pH}$ of soil (Broadley et al., 2012; Hawkesford et al., 2012). Different plant species respond differently to fertilizer rates and combination and a plant species requires balanced fertilizers to maximize growth, yield, and quality (Akamine et al., 2007; Chowdhury et al., 2008; Hafsi et al., 2011). The major nutrients (N, P, and K) applied individually or in combination maintain growth, yield, and quality of plants for their pivotal roles in up-regulating different processes in plants (Akamine et al., 2007; Nakano and Morita, 2009; Hafsi et al., 2011).

Sandy soil has larger particles size and lower CEC, and therefore lower ability to retain nutrients against loss. This type of soil needs a proper NPK fertilization method to take up all nutrient requirements with minimal nutrient loss. Therefore, the main objective of this study was to identify the best NPK application method; integrative soil and leafy application to hot pepper plants when grown in sandy soil to minimize nutrient loss and obtain maximum growth and yield through up-regulation of osmoprotectant and antioxidant compounds and nutrients in plants.

\section{MATERIALS AND METHODS}

\section{Location, plant material, growth conditions, treatments, and experimental layout}

A pot experiment, which was repeated three times at the same time, was carried out in three different locations at the Experimental Farm of the Faculty of Agriculture, South East Fayoum (29 $\left.17^{\circ} \mathrm{N} ; 30^{\circ} 53^{\prime} \mathrm{E}\right)$, Egypt. Transplanting was performed on March 15, 2018 using five-week-old pepper transplants (Capsicum annuum L., "Top Star Hybrid") obtained from the Ministry of Agriculture Nurseries, Cairo, Egypt. Black colored-plastic pots $(35 \mathrm{~cm}$ inner diameter and 355 $\mathrm{cm}$ in depth) were used and each pot was received $10 \mathrm{~kg}$ sandy soil. Physical and chemical properties of the tested soil were determined according to Page et al. (1982) and Klute (1986), and the data are presented in Table 1.

Pepper seedlings were sorted for validity and standardization. One pepper transplant was transplanted in each pot, and the pots were organized in a wire greenhouse under the normal climatic conditions, which were as follows: temperatures range: $27 \pm 3{ }^{\circ} \mathrm{C}$ for day $(12 \mathrm{~h})$ and $17 \pm 2{ }^{\circ} \mathrm{C}$ for night $(12 \mathrm{~h})$, and humidity average: $62-66 \%$. Availability of sunlight (with average $12 \mathrm{~h}$ radiation)

Fayoum J. Agric. Res. \& Dev., Vol. 34, No.2 July, 2020 
Khaulood A. Hemida et al.

inside the greenhouse was kept homogeneous. Pepper transplants were irrigated daily based on the soil field capacity (SFC; 11.9\%), which was determined at the laboratory of soil and water analyses, Department of Soil and Water Science, Faculty of Agriculture, Fayoum University, Fayoum, Egypt, along with other physical and chemical properties (Table 1).

Table 1. Physico-chemical properties of the soil used for experiments

\begin{tabular}{|c|c|c|}
\hline Properties & Unit & Value \\
\hline \multicolumn{3}{|c|}{ Particle size distribution: } \\
\hline Sand & \multirow{3}{*}{$\%$} & 84.6 \\
\hline Silt & & 11.2 \\
\hline Clay & & 4.2 \\
\hline \multicolumn{2}{|c|}{ Texture class } & Sand \\
\hline $\mathrm{OM}$ & \multirow{3}{*}{$\%$} & 0.13 \\
\hline $\mathrm{FC}$ & & 11.9 \\
\hline $\mathrm{CaCO}_{3}$ & & 3.10 \\
\hline $\mathrm{pH}$ & - & 7.57 \\
\hline $\mathrm{EC}_{\mathrm{e}}$ & $\mathrm{dS} \mathrm{m}^{-1}$ & 1.07 \\
\hline CEC & meq $100^{-1}$ g soil & 4.9 \\
\hline \multicolumn{3}{|c|}{ Available macro-nutrients: } \\
\hline $\mathrm{N}$ & \multirow{3}{*}{$\mathrm{mg} \mathrm{kg}^{-1}$ soil } & 17.4 \\
\hline $\mathrm{P}$ & & 10.2 \\
\hline $\mathrm{K}^{+}$ & & 96 \\
\hline
\end{tabular}

$\mathrm{OM}=$ organic matter, $\mathrm{CEC}=$ cation exchange capacity, and $\mathrm{FC}=$ field capacity of soil.

Pepper transplants were assigned to 4 replicates (10 pots for each replicate) of 5 treatments (a total of 200 pots) until harvest for applying treatments. The description of five treatments is presented in Table 2, bearing in mind that the full dose of NPK fertilization added to the soil was specified as a control. Humic acid was added at a rate of $2 \mathrm{~g}$ per pot after transplanting with the first soil addition dose of NPK. Foliar sprays of NPK were carried out using hand atomizer. The volume of the spraying solutions was sprayed to run off, and few drops of Tween20 were used as a surfactant.

Fayoum J. Agric. Res. \& Dev., Vol. 34, No.2 July, 2020 
INTEGRATIVE SOIL AND LEAFY APPLICATION OF NPK. 17

Table 2. Fertilization program (NPK fertilizers amounts and dates of applications) for pepper plants grown on sandy soil

\begin{tabular}{|c|c|c|}
\hline Treat. No. & Soil application & Foliar application \\
\hline 1 & $\begin{array}{l}\mathbf{1 0 0 \%} \text { NPK (4, } 4, \text { and } \mathbf{2} \mathbf{g}, \\
\text { respectively per pot): } 1,1 \text {, and } 0.5 \mathrm{~g} \\
\text { of } \mathrm{N}, \mathrm{P} \text {, and K fertilizers, respectively } \\
\text { were added to the soil of each pot } 4 \\
\text { times; AT, } 25,50 \text {, and } 75 \text { DAT. }\end{array}$ & 0\% NPK \\
\hline 2 & $\begin{array}{l}\mathbf{7 5 \%} \text { NPK }(3, \mathbf{3}, \text { and } 1.5 \mathrm{~g}, \\
\text { respectively per pot): } 0.75,0.75 \text {, and } \\
0.375 \mathrm{~g} \text { of } \mathrm{N}, \mathrm{P} \text {, and } \mathrm{K} \text { fertilizers, } \\
\text { respectively were added to the soil of } \\
\text { each pot } 4 \text { times; AT, } 25,50 \text {, and } 75 \\
\text { DAT. }\end{array}$ & $\begin{array}{l}25 \% \text { NPK }(1,1, \text { and } 0.5 \text { g, respectively } \\
\text { per pot): } 0.25,0.25 \text {, and } 0.125 \mathrm{~g} \text { of } \mathrm{N} \text {, } \\
\mathrm{P} \text {, and K fertilizers, respectively were } \\
\text { applied to the plant in each pot } 4 \text { times; } \\
7,28,49 \text {, and } 70 \text { DAT. }\end{array}$ \\
\hline 3 & $\begin{array}{l}\mathbf{5 0 \%} \text { NPK }(2,2, \text { and } 1 \mathrm{~g} \text {, respectively } \\
\text { per pot): } 0.50,0.50 \text {, and } 0.25 \mathrm{~g} \text { of } \mathrm{N} \text {, } \\
\mathrm{P} \text {, and K fertilizers, respectively were } \\
\text { added to the soil of each pot } 4 \text { times; } \\
\text { AT, } 25 \text { DAT, } 50 \text { DAT, and } 75 \text { DAT. }\end{array}$ & $\begin{array}{l}\mathbf{5 0 \%} \text { NPK }(2,2 \text {, and } 1 \text { g, respectively } \\
\text { per pot): } 0.25,0.25 \text {, and } 0.125 \mathrm{~g} \text { of } \mathrm{N} \text {, } \\
\mathrm{P} \text {, and K fertilizers, respectively were } \\
\text { applied to the plant in each pot } 8 \text { times; } \\
7,17,27,37,47,57,66 \text {, and } 75 \mathrm{DAT} \text {. }\end{array}$ \\
\hline 4 & $\begin{array}{l}25 \% \text { NPK }(\mathbf{1}, \mathbf{1}, \text { and } \mathbf{0 . 5} \mathbf{g}, \\
\text { respectively per pot): } 0.50,0.50 \text {, and } \\
0.25 \mathrm{~g} \text { of } \mathrm{N}, \mathrm{P} \text {, and } \mathrm{K} \text { fertilizers, } \\
\text { respectively were added to the soil of } \\
\text { each pot } 4 \text { times; AT, } 25 \mathrm{DAT}, 50 \\
\text { DAT, and } 75 \mathrm{DAT} \text {. }\end{array}$ & $\begin{array}{l}\mathbf{7 5 \%} \text { NPK }(3,3 \text {, and } 1.5 \text { g, respectively } \\
\text { per pot): } 0.375,0.375 \text {, and } 0.1875 \mathrm{~g} \text { of } \\
\mathrm{N}, \mathrm{P} \text {, and } \mathrm{K} \text { fertilizers, respectively were } \\
\text { applied to the plant in each pot } 8 \text { times; } \\
7,17,27,37,47,57,66 \text {, and } 75 \text { DAT. }\end{array}$ \\
\hline 5 & 0\% NPK & $\begin{array}{l}\text { 100\% NPK }(4,4 \text {, and } 2 \text { g, respectively } \\
\text { per pot): } 0.40,0.40 \text {, and } 0.20 \text { g of } N, P \text {, } \\
\text { and } K \text { fertilizers, respectively were } \\
\text { applied to the plant in each pot } 10 \text { times; } \\
7,15,22,30,37,45,52,60,68 \text {, and } 75 \\
\text { DAT. }\end{array}$ \\
\hline
\end{tabular}

$\mathrm{N}$ (ammonium sulphate, 20.5\% N), $\mathrm{P}$ (calcium superphosphate, $15.5 \% \mathrm{P}_{2} \mathrm{O}_{5}$ ), $\mathrm{K}$ (potassium sulphate, $48 \% \mathrm{~K}_{2} \mathrm{O}$ ), and potassium humate were applied at $4,4,2$, and $2 \mathrm{~g}$ per pot, respectively. $\mathrm{AT}=$ after transplanting directly, and DAT $=$ days after transplanting.

The pots were arranged in a completely randomized design. Weight method was used to irrigate pots daily, where the pots were weighed and watered up to their corresponding target SFC, by replacing the amount of water transpired and evaporated. To avoid bias and systematic error produced by fluctuations in the local environmental conditions, the pots were rotated every two days throughout the experiment duration.

\section{Sampling}

Plant samples were collected 60 days after transplanting (DAT). The shoot system of pepper plants was used for vegetative growth traits, while the upper fully-expanded leaves were used for all physiological and biochemical

Fayoum J. Agric. Res. \& Dev., Vol. 34, No.2 July, 2020 
Khaulood A. Hemida et al.

determinations. Pepper fruit yield was obtained at the end of experiments (90 DAT) to determine the fruit yield components.

\section{Assessment of growth and yield components}

Sixty DAT, nine plants were randomly taken from each treatment to determine growth parameters. Leaf area per plant $\left(\mathrm{m}^{2}\right)$ was measured using a digital Planimeter. Shoot fresh weight per plant $(\mathrm{g})$ was assessed using a digital balance and its dry weight $(\mathrm{g})$ was determined after oven-drying at $70{ }^{\circ} \mathrm{C}$ until constant weight was reached. During harvesting period, all remained pepper plants in each treatment were taken and their yield in terms of fruit number, average weight of fruit $(\mathrm{g})$, and total fruit weight per plant $(\mathrm{kg})$ were recorded.

\section{Determination of osmoprotectant and antioxidant compounds}

After extraction with $96 \%(\mathrm{v} / \mathrm{v})$ ethanol, the content of total soluble sugars ( $\mathrm{mg} \mathrm{g}^{-1}$ dried leaf; DW) was assessed (Irigoyen et al., 1992). Each $0.1 \mathrm{ml}$ of extract was reacted with $3 \mathrm{ml}$ of anthrone reagent [freshly prepared from $150 \mathrm{mg}$ anthrone $+100 \mathrm{ml}$ of $72 \%(\mathrm{v} / \mathrm{v}) \mathrm{H}_{2} \mathrm{SO}_{4}$ ]. The mixture was boiled in a water bath for 10 min. using a Spectronic Spectrophotometer (a Bausch and Lomb-2000), readings at $625 \mathrm{~nm}$ were taken after cooling.

Leaf free proline contents $\left(\mu \mathrm{mol} \mathrm{g} \mathrm{g}^{-1} \mathrm{DW}\right)$ were measured using the rapid colourimetric method, as suggested by Bates et al. (1973). Proline was extracted from $0.5 \mathrm{~g}$ of each leaf sample by grinding in $10 \mathrm{ml} \mathrm{3 \%}(\mathrm{v} / \mathrm{v})$ sulphosalicylic acid and the mixture was then centrifuged at $10,000 \times g$ for $10 \mathrm{~min}$. Two $\mathrm{ml}$ of the supernatant was added to a test tube, to which $2 \mathrm{ml}$ of a freshly prepared acidninhydrin solution was then added. The tubes were incubated in a water bath at $90^{\circ} \mathrm{C}$ for $30 \mathrm{~min}$ and the reaction was terminated in an ice-bath. Each reaction mixture was extracted with $5 \mathrm{ml}$ toluene and vortex-mixed for $15 \mathrm{~s}$. The tubes were allowed to stand for at least $20 \mathrm{~min}$ in the dark at room temperature to allow separation of the toluene and aqueous phases. Each toluene phase was then carefully collected into a clean test tube and its absorbance was read at $520 \mathrm{~nm}$. The free proline concentration in the sample was determined from a standard curve prepared using analytical grade proline, and calculated on a \% DW basis.

The method of Okamura (1980) was followed to determine the content of ascorbic acid (AsA) with the modification of Law et al. (1992). Four hundred $\mu 1$ chlorophyll $(250-350 \mu \mathrm{g})$ was taken into a test tube with $200 \mu \mathrm{l}$ trichloroacetic acid $(10 \%)$ was added. The mixture was mixed in a vortex and cooled by keeping it in an ice for $5 \mathrm{~min}$. To this solution, $10 \mu \mathrm{l} \mathrm{NaOH}(5 \mathrm{M})$ was added and centrifuged for $2 \mathrm{~min}$ in a Microfuge. Supernatant was collected. In one test tube, $200 \mu \mathrm{l}$ supernatant was taken and $200 \mu \mathrm{l}$ of $150 \mathrm{mM} \mathrm{NaH} \mathrm{PO}_{4}$ buffer, $\mathrm{pH} 7.4$, also $200 \mu \mathrm{l}$ of distilled water were added. In another test tube, $200 \mu \mathrm{l}$ supernatant was taken to which $200 \mu \mathrm{l}$ buffer, $100 \mu \mathrm{l}$ of dithiothreitol $(10 \mathrm{mM})$ were added and incubated at room temperature for $15 \mathrm{~min}$. After incubation, $100 \mu \mathrm{N}$ ethylmaleimide $(0.5 \%)$ was added. $400 \mu \mathrm{l}$ trichloroacetic acid (10\%), $400 \mu \mathrm{l}$ $\mathrm{H}_{3} \mathrm{PO}_{4}$ (44\%), $400 \mu \mathrm{l}$ bipyridyl (4\%), 70\% ethanol and $200 \mu \mathrm{l} \mathrm{FeCl}_{3}(3 \%)$ were added to both samples. Samples were incubated at $37{ }^{\circ} \mathrm{C}$ for $60 \mathrm{~min}$ and Optical density was recorded at $A_{525}$. A standard curve in the range 0-40 nmol of AsA was used for calibration. The results were expressed as $\mu$ mol total AsA $\mathrm{g}^{-1} \mathrm{FW}$.

Fayoum J. Agric. Res. \& Dev., Vol. 34, No.2 July, 2020 
INTEGRATIVE SOIL AND LEAFY APPLICATION OF NPK. .19

The GSH content was determined according to the method of Gossett et al. (1994). A weight of $0.5 \mathrm{~g}$ leaves was homogenized in $10 \mathrm{ml} \mathrm{HCl}(0.2 \mathrm{~N})$ and centrifuged at $16,000 \times \mathrm{g}$ for $10 \mathrm{~min}$. Supernatant solution was collected. $500 \mu \mathrm{l}$ supernatant was taken into a test tube and neutralized with sodium phosphate buffer $(0.2 \mathrm{M}), \mathrm{pH}$ 5.6. After neutralization, the extract was added to the reaction mixture consisting of sodium phosphate buffer $(0.2 \mathrm{M})$, pH 7.5, EDTA $(10 \mathrm{mM})$, NADPH $(10 \mathrm{mM})$, DTNB $(12 \mathrm{mM})$ and $20 \mathrm{U} \mathrm{ml}^{-1} \mathrm{GSH}$ reductase enzyme. The results were expressed as $\mu$ mol GSH g ${ }^{-1} \mathrm{FW}$.

\section{Determinations of nutrients}

To assess the macronutrients; nitrogen $(\mathrm{N})$, phosphorus $(\mathrm{P})$, and potassium $\left(\mathrm{K}^{+}\right)$, pepper leaves were dried and grounded to powdered form. $\mathrm{N}$ content was determined using the apparatus of micro-Kjeldahl (Ningbo Medical Instruments Co., Ningbo, China) following A.O.A.C. (1995). The blue color method of Jackson (1967) was followed to assess $\mathrm{P}$ content in which the molybdenum reduced molybdophosphoric in sulphuric acid was used with a reduction to exclude arsenate. Standard reagents such as sulphomolybdic acid $\left(\mathrm{H}_{2} \mathrm{MoO}_{7} \mathrm{~S}\right)$; molybdenum blue, diluted $\mathrm{H}_{2} \mathrm{MoO}_{7} \mathrm{~S}$, and $8 \%$ (w/v) $\mathrm{NaHSO}_{3}-\mathrm{H}_{2} \mathrm{SO}_{4}$ were used. Leaf content of $\mathrm{K}^{+}$was assessed on flame photometer (Perkin-Elmer Model 52-A, Glenbrook, Stamford, CT, USA) as outlined in Page et al. (1982) methods.

\section{Statistical analysis}

Simple analysis of variance (ANOVA) was used to analyse the data. Significant differences between means were compared using Fisher's leastsignificant difference (LSD) test at a probability level of 95\% $(P \leq 0.05)$.

\section{RESULTS}

\section{Effects on growth characteristics of pepper plant}

The integrative treatment of " $50 \%$ of NPK added to the soil $+50 \%$ of NPK added as foliar spray" showed the highest growth characteristics (e.g., leaf area plant $^{-1}$, and shoot fresh and dry weights; FW and DW) of hot pepper plants compared to other integrative treatments [e.g., " $100 \%$ of NPK added to the soil + foliar spray with distilled water (control)", " $75 \%$ of NPK added to the soil $+25 \%$ of NPK added as foliar spray", " $25 \%$ of NPK added to the soil $+75 \%$ of NPK added as foliar spray", and "NPK fertilizers have not been added to the soil + $100 \%$ of NPK added as foliar spray"] (Figure 1). This integrative treatment increased leaf area plant ${ }^{-1}$, shoot FW, and shoot DW by 21.7, 53.0, and 29.7\%, respectively compared to the control treatment (100\% of NPK added to the soil + foliar spray with distilled water). The integrative treatment of " $75 \%$ of NPK added to the soil $+25 \%$ of NPK added as foliar spray" was occupied the second order and significantly increased leaf area plant ${ }^{-1}$, shoot FW, and shoot DW by $8.7,25.3$, and $13.9 \%$, respectively compared to the control treatment.

Fayoum J. Agric. Res. \& Dev., Vol. 34, No.2 July, 2020 


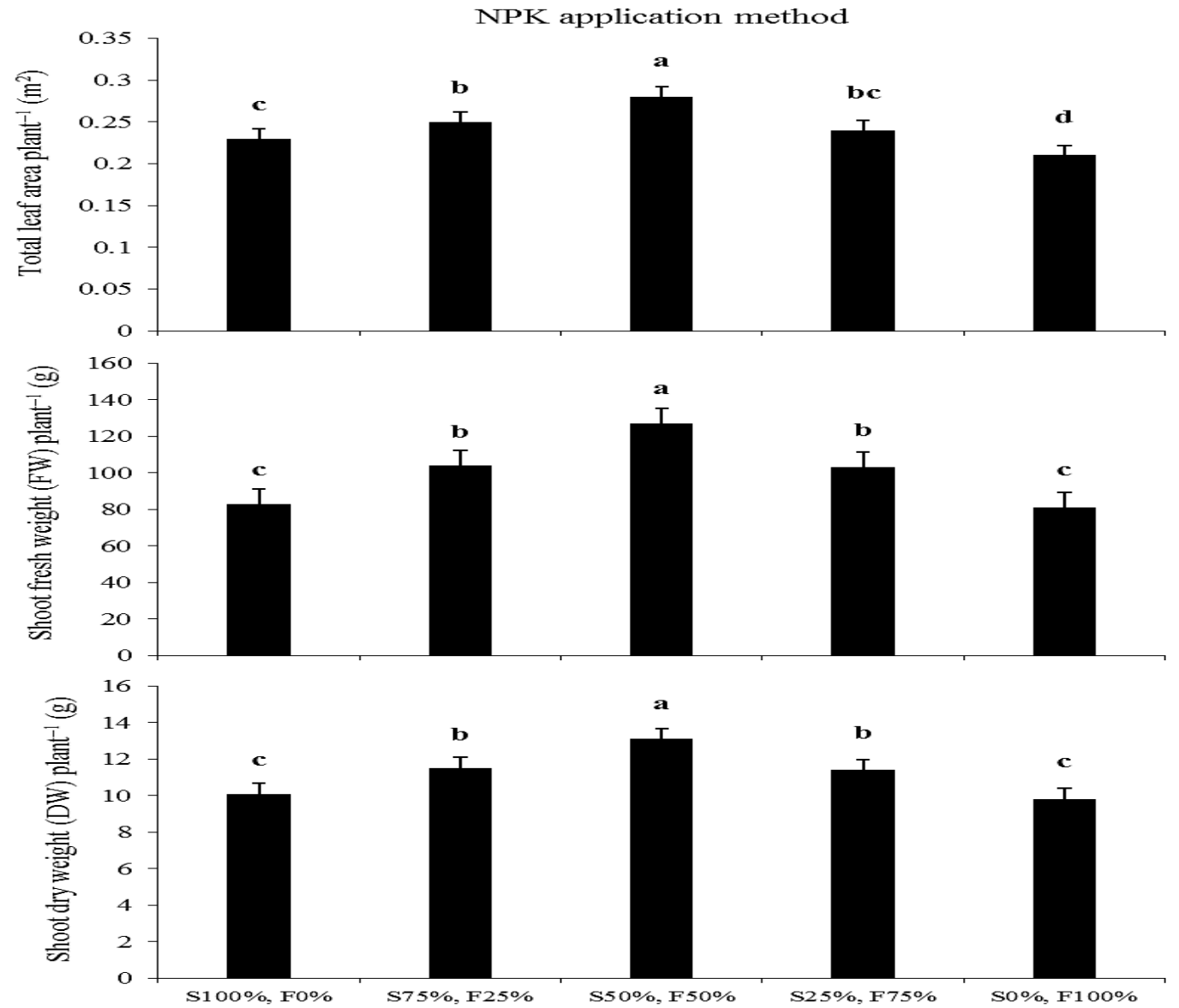

Figure 1. Effect of application method for NPK fertilization on growth characteristics of "Top Star hybrid" sweet pepper (Capsicum annuum L.) plants grown in sandy soil during early summer season, 2018. Data are means \pm SD ( $=$ 9). Different letters in a column indicate significant differences between the treatments at $P \leq 0.05$ level.

S100\%, F0\% means 100\% NPK applied to soil + no foliar application; S75\%, F25\% means 75\% NPK applied to soil $+25 \%$ NPK applied as foliar spray; S50\%, F50\% means 50\% NPK applied to soil $+50 \%$ NPK applied as foliar spray; S25\%, F75\% means 25\% NPK applied to soil $+75 \%$ NPK applied as foliar spray; and S0\%, F100\% means 0\% NPK applied to soil $+100 \%$ NPK applied as foliar spray.

\section{Effects on osmoprotectant and antioxidant compounds contents}

Data in Figure 2 show that the integrative treatment of " $50 \%$ of NPK added to the soil $+50 \%$ of NPK added as foliar spray" exhibited the highest contents of total soluble sugars and free proline, while displayed the lowest contents of ascorbic acid (AsA), and glutathione (GSH) in hot pepper plants compared to other integrative treatments [e.g., " $100 \%$ of NPK added to the soil + foliar spray with distilled water (control)", "75\% of NPK added to the soil $+25 \%$ of NPK added as foliar spray", " $25 \%$ of NPK added to the soil $+75 \%$ of NPK added as foliar spray", and "NPK fertilizers have not been added to the soil $+100 \%$ of NPK added as foliar spray"].

Fayoum J. Agric. Res. \& Dev., Vol. 34, No.2 July, 2020 
INTEGRATIVE SOIL AND LEAFY APPLICATION OF NPK.

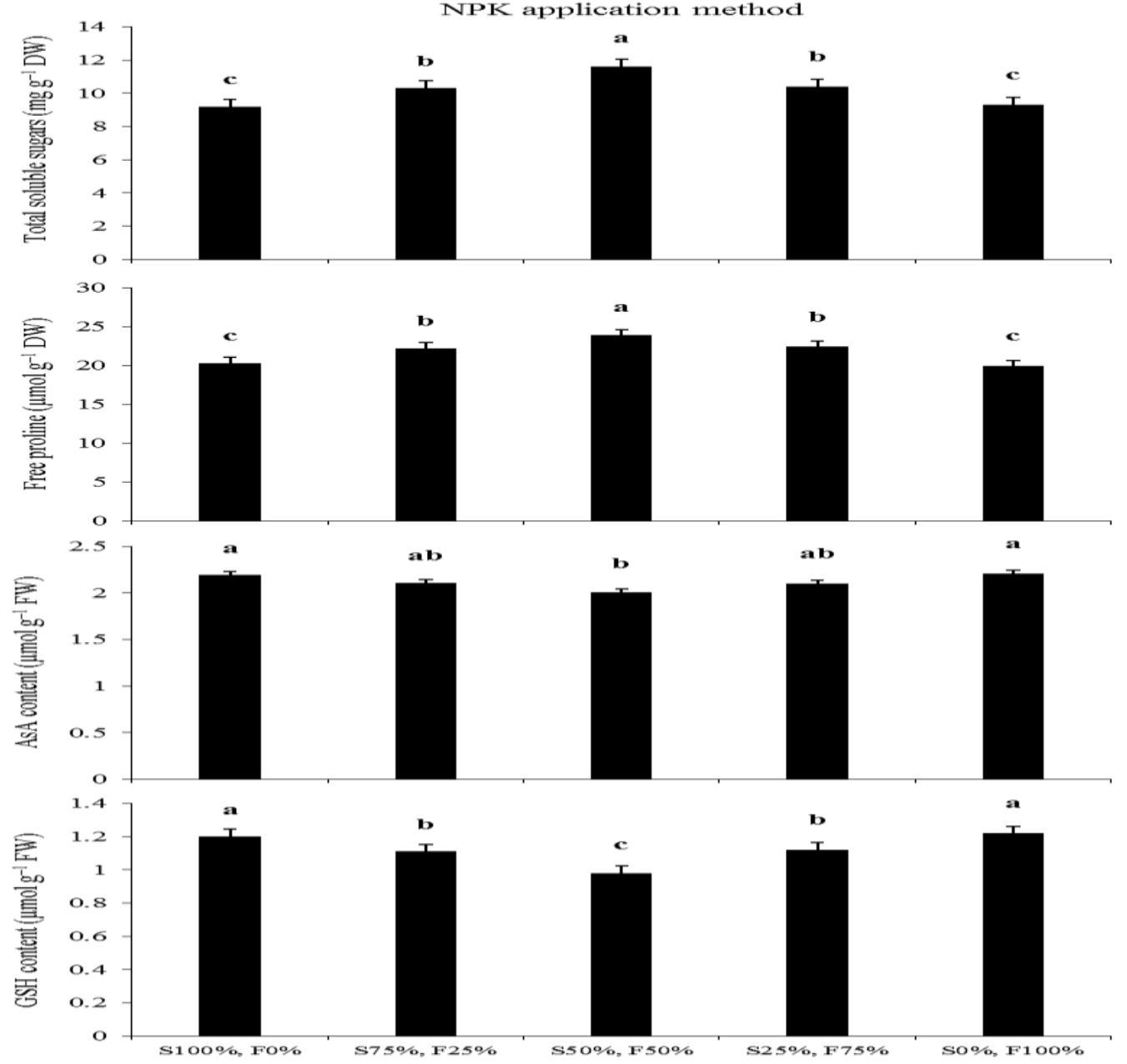

Figure 2. Effect of application method of NPK fertilization on the contents of osmoprotectant and non-enzymatic antioxidant compounds of "Top Star hybrid" sweet pepper (Capsicum annuиm L.) plants grown in sandy soil during early summer season, 2018. Data are means \pm SD $(n=9)$. Different letters in a column indicate significant differences between the treatments at $\mathrm{P} \leq 0.05$ level.

S100\%, F0\% means 100\% NPK applied to soil + no foliar application; S75\%, F25\% means 75\% NPK applied to soil $+25 \%$ NPK applied as foliar spray; S50\%, F50\% means 50\% NPK applied to soil $+50 \%$ NPK applied as foliar spray; S25\%, F75\% means 25\% NPK applied to soil $+75 \%$ NPK applied as foliar spray; and S0\%, F100\% means $0 \%$ NPK applied to soil $+100 \%$ NPK applied as foliar spray.

This integrative treatment increased soluble sugars and free proline contents by 26.1 and $17.7 \%$, respectively, while reduced AsA, and GSH contents by 8.2 and $18.3 \%$, respectively compared to the control treatment (100\% of NPK added to the soil + foliar spray with distilled water). The integrative treatments of " $75 \%$ of NPK added to the soil $+25 \%$ of NPK added as foliar spray" and " $25 \%$ of NPK added to the soil $+75 \%$ of NPK added as foliar spray" were in equal status with respect to increasing soluble sugars and proline contents and reducing AsA and GSH contents and occupied the second order after the best integrative treatment.

Fayoum J. Agric. Res. \& Dev., Vol. 34, No.2 July, 2020 
Khaulood A. Hemida et al.

\section{Effects on macronutrient ( $N, P$, and $K$ ) contents}

The integrative treatment of " $50 \%$ of NPK added to the soil $+50 \%$ of NPK added as foliar spray" showed the highest contents of $\mathrm{N}, \mathrm{P}$, and $\mathrm{K}$ in hot pepper plants compared to other integrative treatments [e.g., " $100 \%$ of NPK added to the soil + foliar spray with distilled water (control)", "75\% of NPK added to the soil + $25 \%$ of NPK added as foliar spray", " $25 \%$ of NPK added to the soil $+75 \%$ of NPK added as foliar spray", and "NPK fertilizers have not been added to the soil $+100 \%$ of NPK added as foliar spray"] (Figure 3). This integrative treatment increased $\mathrm{N}, \mathrm{P}$, and $\mathrm{K}$ contents by $21.8,17.7$, and $19.7 \%$, respectively compared to the control treatment $(100 \%$ of NPK added to the soil + foliar spray with distilled water). The integrative treatment of " $75 \%$ of NPK added to the soil + $25 \%$ of NPK added as foliar spray" was occupied the second order and significantly increased $\mathrm{N}, \mathrm{P}$, and $\mathrm{K}$ contents by $11.9,7.3$, and $10.5 \%$, respectively compared to the control treatment.

\section{Effects on yield components of pepper plants}

Data in Figure 4 show that the integrative treatment of " $50 \%$ of NPK added to the soil $+50 \%$ of NPK added as foliar spray" exhibited the highest yield components (e.g., number of fruits plant ${ }^{-1}$, average fruit weight, and fruits weight plant $^{-1}$ ) of hot pepper plants compared to other integrative treatments [e.g., " $100 \%$ of NPK added to the soil + foliar spray with distilled water (control)", " $75 \%$ of NPK added to the soil $+25 \%$ of NPK added as foliar spray", " $25 \%$ of NPK added to the soil $+75 \%$ of NPK added as foliar spray", and "NPK fertilizers have not been added to the soil $+100 \%$ of NPK added as foliar spray"]. This integrative treatment increased number of fruits plant ${ }^{-1}$, average fruit weight, and fruits weight plant ${ }^{-1}$ by $67.6,48.0$, and $145.9 \%$, respectively compared to the control treatment (100\% of NPK added to the soil + foliar spray with distilled water). The integrative treatment of " $75 \%$ of NPK added to the soil $+25 \%$ of NPK added as foliar spray" was occupied the second order and significantly increased number of fruits plant ${ }^{-1}$, average fruit weight, and fruits weight plant $^{-1}$ by $35.3,13.0$, and $51.4 \%$, respectively compared to the control treatment.

Fayoum J. Agric. Res. \& Dev., Vol. 34, No.2 July, 2020 
INTEGRATIVE SOIL AND LEAFY APPLICATION OF NPK.

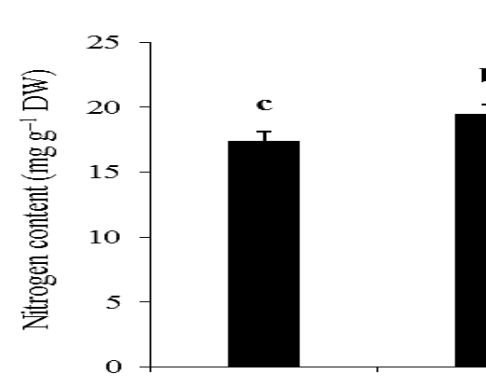

NPK application method

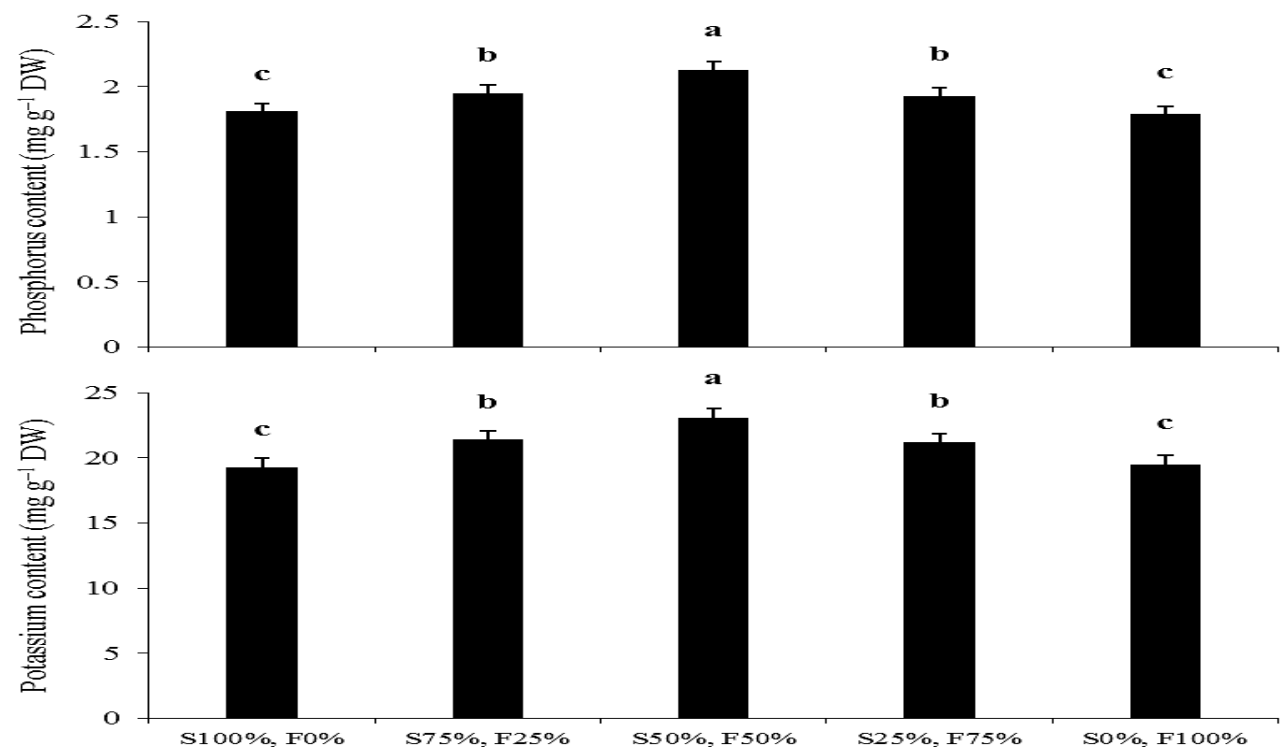

Figure 3. Effect of application method of NPK fertilization on nutrient contents of "Top Star hybrid" sweet pepper (Capsicum annuиm L.) plants grown in sandy soil during early summer season, 2018. Data are means \pm SD $(n=9)$. Different letters in a column indicate significant differences between the treatments at $P \leq 0.05$ level.

S100\%, F0\% means 100\% NPK applied to soil + no foliar application; S75\%, F25\% means 75\% NPK applied to soil + 25\% NPK applied as foliar spray; S50\%, F50\% means 50\% NPK applied to soil $+50 \%$ NPK applied as foliar spray; S25\%, F75\% means 25\% NPK applied to soil $+75 \%$ NPK applied as foliar spray; and S0\%, F100\% means 0\% NPK applied to soil $+100 \%$ NPK applied as foliar spray.

Fayoum J. Agric. Res. \& Dev., Vol. 34, No.2 July, 2020 

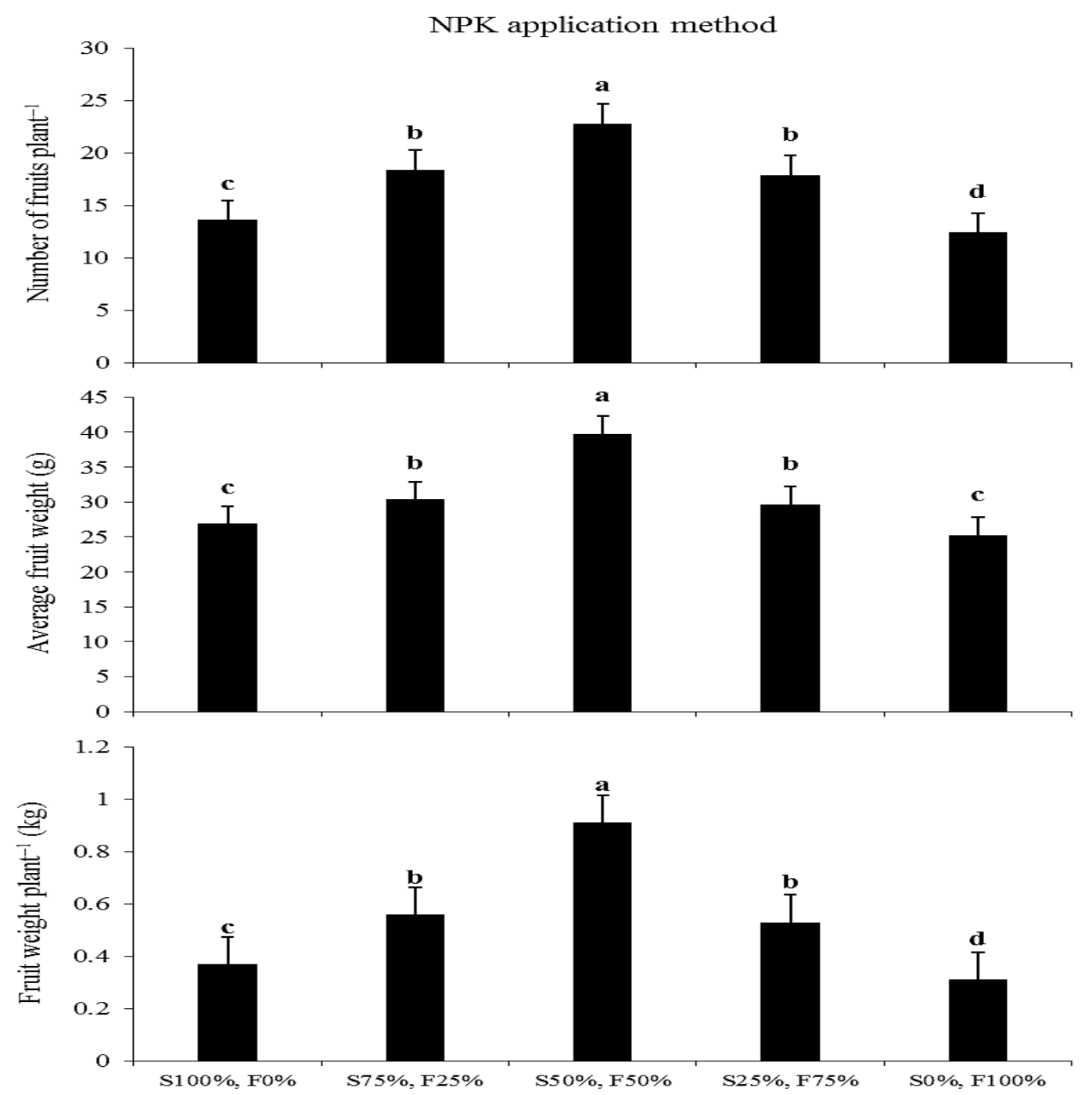

Figure 4. Effect of application method of NPK fertilization on yield characteristics of "Top Star hybrid" sweet pepper (Capsicum annuum L.) plants grown in sandy soil during early summer season, 2018. Data are means \pm SD $(n=$ 9). Different letters in a column indicate significant differences between the treatments at $P \leq 0.05$ level.

S100\%, F0\% means 100\% NPK applied to soil + no foliar application; S75\%, F25\% means 75\% NPK applied to soil $+25 \%$ NPK applied as foliar spray; S50\%, F50\% means 50\% NPK applied to soil $+50 \%$ NPK applied as foliar spray; S25\%, F75\% means 25\% NPK applied to soil $+75 \%$ NPK applied as foliar spray; and S0\%, F100\% means 0\% NPK applied to soil $+100 \%$ NPK applied as foliar spray.

\section{DISCUSSION}

One of the important functions of the soil for plants is the provision of nutrients, which were previously preserved when added to the soil as a fertilizer. Texture is one of soil physical properties that affect preserving nutrients of fertilizers on its particles and their availability to plants to induce their growth and productivity.

Fayoum J. Agric. Res. \& Dev., Vol. 34, No.2 July, 2020 
INTEGRATIVE SOIL AND LEAFY APPLICATION OF NPK.

As one of the the major soil types, sandy soil contains particles that can be seen with the naked eye and provides excellent aeration and drainage. However, this soil tends to erode easily and has a very low ability to retain water and nutrients.

According to the texture of sandy soil, there should be an effective fertilization method that reduces nutrient loss as much as possible for achieving plant productivity and sustainability. Foliar/leafy fertilization has been proven in the past decades to be of great commercial importance worldwide. The rationale for using foliar fertilizers includes the following: (1) when the soil conditions limit the availability of nutrients applied to the soil for plants, (2) in conditions where high levels of nutrients applied to the soil may be lost, and (3) when the stage of plant growth the internal plant demand and the environmental conditions interact to limiting delivery of nutrients to critical plant organs (Femandee and Brown, 2013). Therefore, NPK foliar application has become a concern of scientists for its dynamic application with the aim of increasing plant growth and yield (Ling and Silberbush, 2002; Jamal et al., 2006; Hamayun et al., 2011).

The use of different fertilizers has a major impact on crop growth characteristics, including hot peppers. Using the sand soil, leaf area plant ${ }^{-1}$, shoot FW and DW of hot pepper plant (Figure 1) were obtained at highest increases with the integrative treatment of " $50 \%$ of NPK added to the soil $+50 \%$ of NPK added as foliar spray" comparing with other integrative ones [e.g., " $100 \%$ of NPK added to the soil + foliar spray with distilled water (control)", "75\% of NPK added to the soil $+25 \%$ of NPK added as foliar spray", " $25 \%$ of NPK added to the soil $+75 \%$ of NPK added as foliar spray", and "NPK fertilizers have not been added to the soil $+100 \%$ of NPK added as foliar spray"]. This result may be explained on the basis that sandy soil has a very low cation exchange capacity (CEC; 4.9 meq $100^{-1} \mathrm{~g}$ of soil, Table 1) and a large rate of nutrient loss. Manickam et al. (2015) reported that sandy soil is a problem due to excessive drainage of water and diminishing contents of organic matter, clay and nutrients, as well as the very low CEC. Water and nutrients are easily leached out of this soil due to the low field capacity (FC) and the low CEC, respectively, so water and nutritious stress is common. Therefore, it is difficult for plants to obtain all fertilizer requirements from such soil. To overcome this problem, the integrative strategy of applying fertilizers was used in this study to soil along with the plant foliage. For example, the sandy soil should receive $50 \%$ of the recommended NPK dose and plants should receive another $50 \%$ of NPK as leafy spray as an integrative treatment. Foliar spraying of NPK is an effective method for plants that take up nutrients through stomata as quickly as possible in order to offset nutrient requirements, which cannot be taken from sandy soil due to their rapid loss.

Macro-elements were increased significantly by the best integrative treatment of " $50 \%$ of NPK added to the soil $+50 \%$ of NPK added as foliar spray" (Table 3 ) due to providing plants effectively with the required nutrients compared to other integrative treatments. They are known to enhance plant growth characteristics due to the role of $\mathrm{N}$ as an essential component of nucleic acids and protein

Fayoum J. Agric. Res. \& Dev., Vol. 34, No.2 July, 2020 
synthesis, $\mathrm{P}$ as an essential component of phosphoprotein and energy compounds, and $\mathrm{K}$ as an activator of many enzymes (Helgi and Rolfe, 2005; Singh et al., 2015).

Like growth characteristics, yield and its components of hot pepper plants had the same trend with the integrative treatment of " $50 \%$ of NPK applied to the soil $+50 \%$ of NPK applied as foliar spray" with sandy soil compared to all other integrative treatments (Figure 4). These improvements in the yield and its components of hot pepper plants are positive reflections of the improved growth characteristics (Figure 1). These results are partly consistent with those obtained by Suge et al. (2011) on eggplants and El-Hamady et al. (2017) on pepper plants.

In general, the highest levels of osmoprotectant compounds (e.g., total soluble sugars, free proline) and the lowest levels of antioxidants (e.g., ascorbate and glutathione) were obtained with the integrative treatments that conferred the best growth and yield components on sandy soil (Figures 1 and 4). The increased contents of the osmoprotectant compounds may be for use to regulate osmotic homeostasis in plants versus rapid leakage of water from sandy soils, while the decreased contents of the antioxidants may be due to overcoming stress by retaining water and nutrients in plants.

\section{REFERENCES}

A.O.A.C. (1995): In: Official methods of analysis of the association of official agricultural chemists, sixteenth ed. Washington, DC, USA.

Akamine, H., Hossain, M. A., Ishimine, Y., Yogi, K., Hokama, K., Iraha, Y. and Aniya, Y. (2007): Effects of application of N, P and $\mathrm{K}$ alone or in combination on growth, yield and curcumin content of turmeric (Curcuma longa L.). Plant Prod. Sci., 10: 151-154.

Alexander A. (1986): Optimum timing of foliar nutrient sprays. pp. 44-60. In: A. Alexander (Ed.). Foliar fertilization. Martinus nijhoff publishers, Dordrecht.

Alshaal, T. and El-Ramady., H. (2017): Foliar Application: from Plant nutrition to biofortification. Environ. Biodiv. Soil Secur., 1: 71- 83.

Bates, L.S., Waldren, R.P. and Teare, I.D. (1973): Rapid determination of free proline for water stress studies. Plant Soil, 39: 205-207.

Bertol, I., Mello, E.L., Guadagnin, J.C., Zaparolli, A.L.V. and Carrafa, M.R. (2003): Nutrient losses by water erosion. Sci. Agric., 60(3): 581-586.

Broadley, M., Brown, P., Cakmak, I., Rengel, Z. and Zhao, F. (2012a): Functions of macronutrients: Micronutrients. In: Marschner, P. (ed.), Marschner's mineral nutrition of higher plants, pp. 191-248.

Chowdhury, A.H.M.R.H., Rahman, G.M.M., Saha, B.K. and Chowdhury, M.A.H. (2008): Addition of some tree leaf litters in forest soil and their effect on the growth, yield and nutrient uptake by red amaranth. J. Agrofor. Environ., 2: 1-6.

CUCE (Cornell University Cooperative Extension) (2007): Cation Exchange Capacity (CEC). Agronomy Fact Sheet Series \#22. Department of Crop and Soil Sciences, College of Agriculture and Life Sciences, Cornell University.

Fayoum J. Agric. Res. \& Dev., Vol. 34, No.2 July, 2020 
INTEGRATIVE SOIL AND LEAFY APPLICATION OF NPK.

Dagnoko, S., Yaro-Diarisso, N., Sanogo, P.N., Adetula, O., Dolo-Nantoumé,

A., Gamby-Touré, K., Traoré-Théra, A., Katilé, S. and Diallo-Ba,

D. (2013): Overview of pepper (Capsicum spp.) breeding in West Africa. Afr. J. Agric. Res. 8(13): 1108-1114.

Dordas, C. (2008): Role of nutrients in controlling plant diseases in sustainable agriculture - a review. Agron. Sustain. Dev., 28: 33-46.

El-Hamady, M.M., Baddour, A.G., Sobh, M.M., Ashour, H.M. and Manaf, H.H. (2017): Influence of mineral fertilization in combination with khumate, amino acids and sodium selenite on growth, chemical composition, yield and fruit quality of sweet pepper plant. Middle East J. Agric. Res. 6(2): 433-447.

Fageria, N.K., Filho, Barbosa, M.P., Moreira, A. and Guimarães, C.M. (2009): Foliar Fertilization of Crop Plants. J. Plant Nutr., 32(6): 10441064.

FAOSTAT (2012): Food and Agricultural Organization of the United Nations Statistical Database, Rome, Italy.

Fernández, V. and Brown, P.H. (2013): From plant surface to plant metabolism: the uncertain fate of foliar-applied nutrients. Front. Plant Sci., 4: 289.

Gossett, D.R., Millhollon, E.P. and Lucas, M.C. (1994): Antioxidant responses to $\mathrm{NaCl}$ stress in salt-sensitive cultivars of cotton. Crop Sci., 34: 706714.

Grubben, G.J.H. and El Tahir, I.M. (2004): Capsicum annuиm L. In: Grubben, GJH \& OA Denton (eds.). PROTA 2: Vegetables/Légumes. [CD-Rom]. PROTA, W ageningen, The Netherlands.

Hafsi, C., Atia, A., lakhdar, A., Dabez, A. and Abdelly, C. (2011): Differential responses in potassium absorption and use efficiencies in the halophytes Catapodium rigidum and Hordeum maritinum to various potassium concentrations in the medium. Plant Prod. Sci., 14: 135140.

Hamayun, M., Khan, S.A., Khan, A.L., Shinwari, Z.K., Ahmad, N., Kim, Y.H., Lee, I.J. (2011): Effect of foliar and soil application of nitrogen, phosphorus and potassium on yield components of lentil. Pak. J. Bot., 43(1): 391-396.

Hawkesford, M., Horst, W., Kichey, T., lambers, H., Schjoerring, J., Skrumsager, M., and White, P. (2012): Functions of macronutrients. In P. Marschner (ed.), Marschner's mineral nutrition of higher plants, pp. 135-189, Amsterdam, Elsevier.

Hazelton, P.A. and Murphy, B.W. (2007): Interpreting soil test results: what do all the numbers mean? Csiro publishing: Melbourne.

Helgi, O. and Rolfe, S.A. (2005): The Physilogy of Flowering Plants. $4^{\text {th }}$ Edn., Cambridge University Press, Cambridge UK., pp: 392.

Irigoyen, J.J., Einerich, D.W. and Sánchez-Díaz, M. (1992): Water stress induced changes in concentrations of proline and total soluble sugars

Fayoum J. Agric. Res. \& Dev., Vol. 34, No.2 July, 2020 
Khaulood A. Hemida et al.

in nodulated alfalfa (Medicago sativa) plants. Physiol. Plant. 84(1): 55-60.

Islam, M.M., Karim, A.J.M.S., Jahiruddin, M., Majid, N.M., Miah, M.G., Ahmed, M.M. and Hakim, M.A. (2011): Effects of organic manure and chemical fertilizers on crops in the radish-stem amaranth-indian spinach cropping pattern in homestead area. Aust. J. Crop Sci., 5: 1370-1378.

Jackson, M.L. (1967): Soil Chemical Analysis. Prentice Hall of India Pvt. Ltd, New Delhi, India, pp. 144-197, 326-338.

Jamal, Z., Hamayun, M., Ahmad, N., Chaudhary, M.F. (2006): Effect of soil and foliar application of different concentrations of NPK and foliar application of $\left(\mathrm{NH}_{4}\right)_{2} \mathrm{SO}_{4}$ on different yield parameters in wheat. $\mathrm{J}$. Agron. 5(2): 251-256.

Klute, A. (1986): Methods of Soil Analysis. Part 1: Physical and Mineralogical Methods, $2^{\text {nd }}$ ed. American Society of Agronomy Madison, Wiscinsin, USA.

Law, M.Y., Charles, S.A. and Halliwell, B. (1992): Glutathione and ascorbic acid in spinach (Spinacea oleracea) chloroplast: the effect of hydrogen peroxide and paraquat. Biochem. J., 210: 899-903.

Ling, F., Silberbush, M. (2002): Response of maize to foliar vs. soil application of nitrogen-phosphorus-potassium fertilizers. J. Plant Nutr., 25(11): 2333-2342.

Magdoff, F. and van Es, H.M. (2009): Building Soils for Better Crops. Beltsville, Md., 2009. Sustainable Agriculture Research and Education Program.

Manickam, T., Cornelissen, G., Bachmann, R.T., Ibrahim, I.Z., Mulder, J. and Hale, S.E. (2015): Biochar Application in Malaysian Sandy and Acid Sulfate Soils: Soil Amelioration Effects and Improved Crop Production over Two Cropping Seasons. Sustainability, 7: 1675616770.

Mello, E.L. (2002): Erosão hídrica em diferentes sistemas de manejo do solo sob chuva simulada. Lages: UDESC/CCA., 2002, 88 p. (Dissertação Mestrado).

Mondal, T., Datta, J.K. and Mondal, N.K. (2015): Influence of indigenous inputs on the properties of old alluvial soil in a mustard cropping system. Arch. Agron. Soil Sci., 61(9): 1319-1332.

Nakano, H. and Morita, S. (2009): Effects of planting time and nitrogen application on dry matter yield of the forage rice cultivar tachiaoba in southwestern Japan. Plant Prod. Sci., 12: 351-358.

Okamura, M. (1980): An improved method for determination of 1-ascorbic acid and 1-dehydroascorbic acid in blood plasma. Clin. Chim. Acta, 103: 259-268.

Oosterhuis, D.M. (1995): Potassium nutrition of cotton in the USA, with particular reference to foliar fertilization. In: G.A. Constable and N.W.

Fayoum J. Agric. Res. \& Dev., Vol. 34, No.2 July, 2020 
INTEGRATIVE SOIL AND LEAFY APPLICATION OF NPK..................29

Forrester (Eds.). Challenging the Future: Proc. World Cotton Conference-1. Brisbane Australia. CSIRO, Melbourne. pp. 133-146.

Oosterhuis, D.M. and Weir, B.L. (2010): Foliar fertilization of cotton. In: Stewart, J.M.D., et al. (Eds.), Physiology of Cotton. DOI 10.1007/978-90-481-3195-2-25, Springer Science + Business Media B.V., p: 272-288.

Page, A.I., Miller, R.H. and Keeney, D.R. (1982): In: Methods of Soil Analysis. Part 2: Chemical and Microbiological Properties, second ed. American Society Agronomy, Madison, Wisconsin, USA.

Schick, J., Bertol, I., Balbinot, J.R., Batistela, A.A. and Eros, O. (2000): ohİdrica em Cambissolo Himico alumInico submetido a diferentessistemas de preparo e cultivo do solo. Perdas de nutrientes e carbonoorg,nico. Revista Brasileira de CiÍncia do Solo, 24: 437-447.

Singh, K.A., Kumar, A. and Yadav, A.L. (2015): Effect of pruning intensity, foliar feeding pf P.G.R. and micronutrientson physico-chemical attributes of Phalsa (Grewia subinaequalis) fruits. Res. Environ. Life Sci. 8(4): 675-678.

Smoleń S. (2012): Foliar Nutrition: Current State of Knowledge and Opportunities. In: A. K. Srivastava (Ed.), Advances in Citrus Nutrition, DOI10.1007/978-94-007-4171-3-4, Springer Science + Business Media, pp. 41-58.

Stepien, A. and Katarzyna, W. (2016): Effect of foliar application of $\mathrm{Cu}, \mathrm{Zn}$, and $\mathrm{Mn}$ on yield and quality indicators of winter wheat grain. Chilean J. Agric. Res., 76(2): 220-227.

Suge, J.K, Omunyin, M.E. and Omami, E.N. (2011): Effect of organic and inorganic sources of fertilizer on growth, yield and fruit quality of eggplant (Solanum melongena L). Arch. Appl. Sci. Res., 3(6): 470479.

Yolcubal, I., Brusseau, M.L., Artiola, J.F., Wierenga, P. and Wilson, L.G. (2004): Environmental physical properties and processes. Environmental monitoring and characterization, pp. 207-239.

Fayoum J. Agric. Res. \& Dev., Vol. 34, No.2 July, 2020 
التطبيق الورقي المتكامل مع التربة لأسمدة NPK يحسن النمو، المحصول، الحالة المضادة ل للأكسدة والحالة الغذائية للفلفل

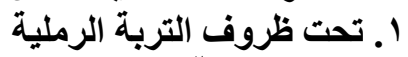

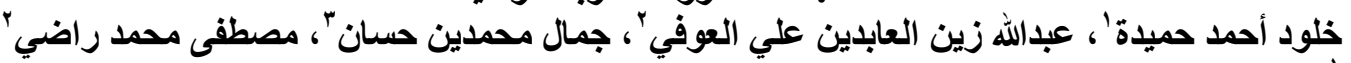

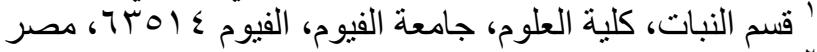

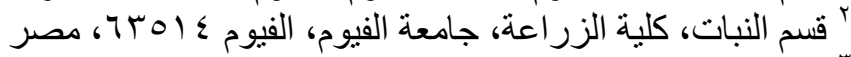

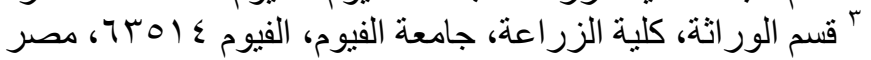

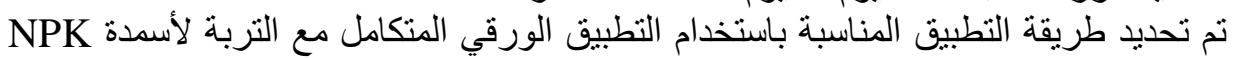

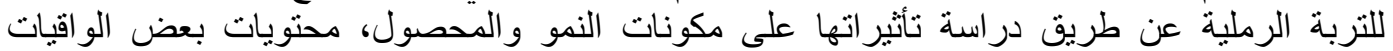

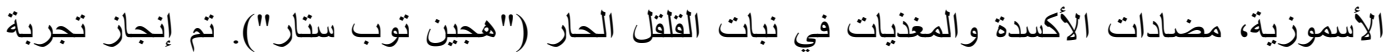

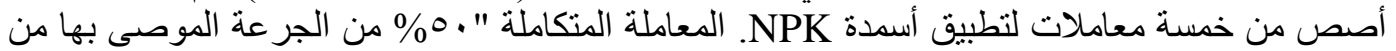

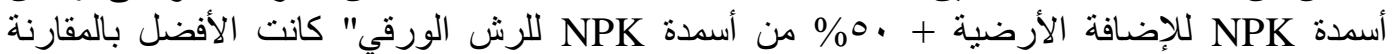

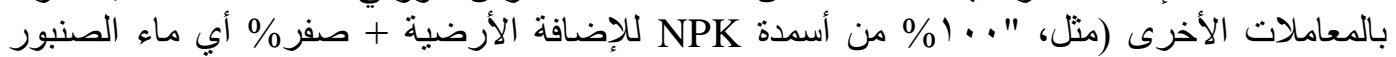

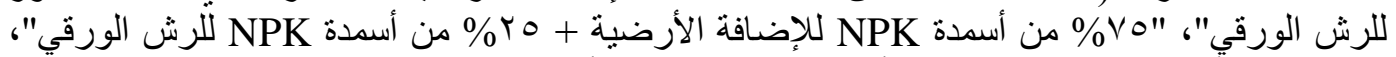

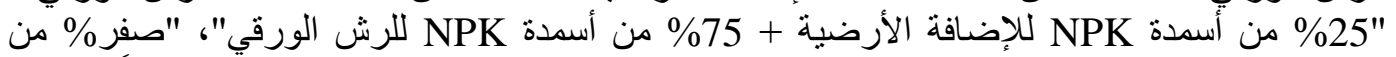

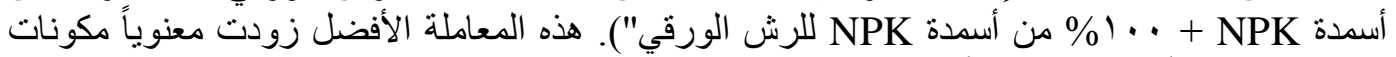

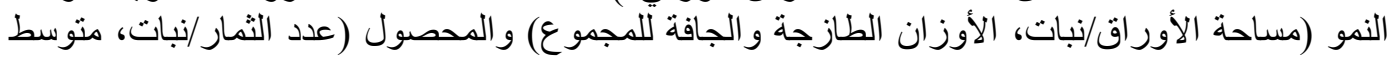

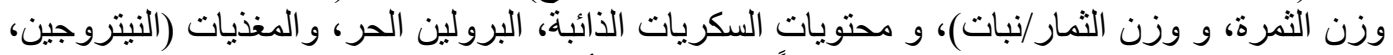

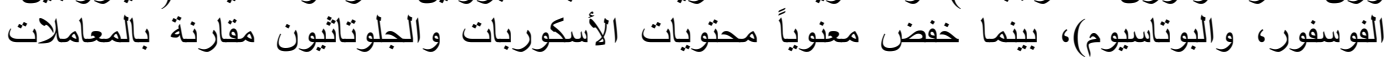

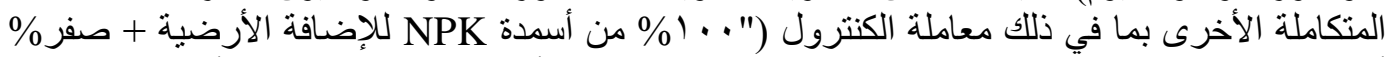

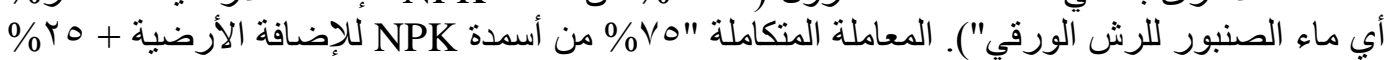

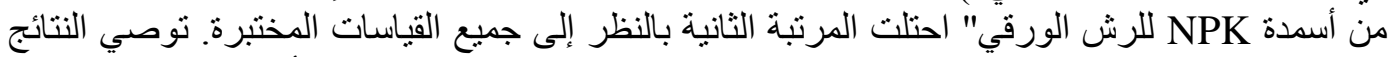

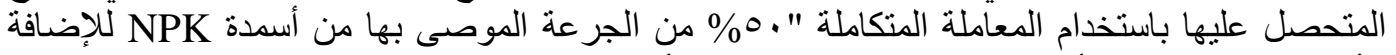

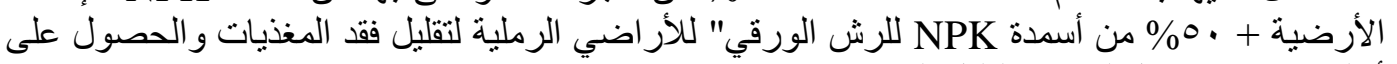

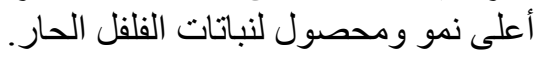
الكلمات المفتاحية: الفلفل، تطبيق المغذيات، الأرض الفئل الرملية، النمو و الإنتاجية، مضادات الأكسدة.

Fayoum J. Agric. Res. \& Dev., Vol. 34, No.2 July, 2020 